\title{
Are Ballot Initiative Outcomes Influenced by the Campaigns of Independent Groups? A Precinct- Randomized Field Experiment
}

\section{Citation}

Rogers, Todd, and Joel A. Middleton. 2012. Are Ballot Initiative Outcomes Influenced by the Campaigns of Independent Groups? A Precinct-Randomized Field Experiment. HKS Faculty Research Working Paper Series RWP12-049, John F. Kennedy School of Government, Harvard University.

\section{Published Version}

http://web.hks.harvard.edu/publications/workingpapers/citation.aspx?Publd=8643

\section{Permanent link}

http://nrs.harvard.edu/urn-3:HUL.InstRepos:9830357

\section{Terms of Use}

This article was downloaded from Harvard University's DASH repository, and is made available under the terms and conditions applicable to Other Posted Material, as set forth at http:// nrs.harvard.edu/urn-3:HUL.InstRepos:dash.current.terms-of-use\#LAA

\section{Share Your Story}

The Harvard community has made this article openly available.

Please share how this access benefits you. Submit a story.

Accessibility 


\title{
Are Ballot Initiative Outcomes Influenced by the Campaigns of Independent Groups? A Precinct-Randomized Field Experiment Faculty Research Working Paper Series
}

\section{Todd Rogers}

Harvard Kennedy School

\author{
Joel A. Middleton
}

New York University

\section{November 2012 RWP12-048}

Visit the HKS Faculty Research Working Paper series at:

http://web.hks.harvard.edu/publications

The views expressed in the HKS Faculty Research Working Paper Series are those of the author(s) and do not necessarily reflect those of the John F. Kennedy School of Government or of Harvard University. Faculty Research Working Papers have not undergone formal review and approval. Such papers are included in this series to elicit feedback and to encourage debate on important public policy challenges. Copyright belongs to the author(s). Papers may be downloaded for personal use only. 


\title{
Are Ballot Initiative Outcomes Influenced by the Campaigns of Independent Groups?
}

\section{A Precinct-Randomized Field Experiment}

\begin{abstract}
(149 words)
Ballot initiatives are consequential and common, with total spending on initiative campaigns in the US rivaling that of Presidential campaigns. Observational studies using regression approaches on observational data have alternately found that initiative campaign spending cannot affect initiative outcomes, can increase the number of votes rejecting (but not approving) initiatives, or can affect outcomes in either direction. We report the first well-powered precinctrandomized field experiment to evaluate an initiative advocacy campaign. We find that campaigns can influence both rejection and approval of initiatives by changing how citizens vote, as opposed to by influencing turnout or ballot completion. Our experiment (involving around $18 \%$ of Oregon households in 2008) studied a statewide mail program conducted by a Political Action Committee. Results further suggest that two initiatives would have passed if not for the advocacy campaign to reject them. We discuss implications for theories about direct democracy, campaign finance, and campaign effects.
\end{abstract}

(Under Review)

Word Count: 4,963

Todd Rogers

Center for Public Leadership, Harvard Kennedy School

Joel A. Middleton

Steinhardt School, New York University

We thank Josh Berezin and Defend Oregon for their help in developing and implementing the program we study in this manuscript, and for compiling and collecting data for this research. We thank the Analyst Institute for organizational help. We thank Don Green and Analyst Group 
participants for feedback; and Seth Masket, Carly Robinson and Julia Kamin for assistance. This work was presented at the Midwest Political Science Association conference in 2011.

Ballot initiatives are a consequential, common, and costly aspect of American politics. This form of direct democracy can determine laws that have important economic and social consequences. Moreover, ballot initiatives may have implications for civic participation. Voters in states with ballot initiatives tend to be more engaged, exhibiting higher turnout (Tolbert and Smith 2005) and greater political awareness (Nicholson 2003). Because the stakes can be high, substantial resources are often devoted to advocating for and against them, and total spending on initiative campaigns can rival that of Presidential campaigns (Gerber 1999; Initiative and Referendum Institute 2000).

There is no clear consensus on whether ballot initiative campaigns affect initiative outcomes. Observational studies have come to a variety of conclusions while using regression frameworks that examine how money, interest group involvement, or advertising as independent variables affect initiative success as the dependent variable. Some have concluded that initiative campaigns have no effect on initiative outcomes (Gerber 1999; Bowler and Donovan 1998), others suggest they do (Stratmann 2006; Smith 2004), and still others say that they are effective but only when advocating for rejection, not passage (Garrett and Gerber 2001; for a descriptive analysis see Broder 2000). Furthermore, this past research is unable to speak directly to whether ballot initiative campaigns influence outcomes by changing how citizens vote or by changing whether they vote.

In this manuscript, we offer robust evidence that campaigns can have profound effects on initiative outcomes in either direction, by changing how citizens vote. To assess the causal impact of initiative advocacy, we report a well-powered precinct-randomized experiment 
conducted during a statewide ballot initiative campaign. In addition to addressing questions about the impact of initiative campaigns, the research speaks to questions of campaign effectiveness, more generally (e.g., Gelman and King 1993; Holbrook 1996; Gerber 2004; Stratmann 2005).

We worked with a Political Action Committee (PAC) that sought to sway the outcome of twelve ballot initiatives in the 2008 General Election in Oregon by sending one or two informative ballot guides to most households in the state. Out of twelve initiatives, the organization advocated for the passage of four and the rejection of eight. We find statistically and substantively significant effects on ten of the twelve initiatives. For two initiatives, it appears that effects were large enough to have altered the election outcome; the initiatives were rejected but would have passed were it not for the ballot guides.

Interestingly, the treatment had no effect on overall turnout or on rates of ballot roll-off (i.e., failure to cast a vote on given initiative despite submitting a ballot). Taken together, the pattern of results suggests that the treatment affected vote margins by altering preferences among those who would have voted on the initiatives anyway, but in the other direction.

This manuscript proceeds as follows. We begin with a review of past research on the effect of initiative campaigns. We then discuss the electoral context in which this study takes place and describe the advocacy program. We then discuss the precinct randomized design and the analysis plan of our field experiment involving 320,921 registered voters. Finally, we report the results of the experiment in terms of net vote margin, turnout, ballot roll-off, and effects on "up-ballot" political races. We conclude by discussing the implications of this research.

\section{PAST RESEARCH}


With little exception, research on ballot initiative campaigns has retrospectively analyzed existing datasets. Almost no research on this topic has used field experiments to identify causal effects, despite the emergence of field experiments in political science to study voter mobilization effects (Gerber and Green 2000; Gerber and Green 2004), and other campaign

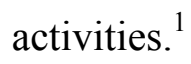

One exception was Keane and Nickerson (2012). Using a precinct-randomized field experiment, they found that a coalition advocating for the rejection of five initiatives decreased support for all five initiatives, but they note several limitations. First, unlike the present study, their study was under powered. Power was limited by the number of precincts in the study and the low rates of reaching targeted individuals in the canvass programs they studied. Second, whereas we disentangle the differential effects of persuasion from turnout and ballot roll-off, their lack of statistical power made such analyses impossible. Third, the advocacy campaign they study advocated for rejecting all initiatives. In the present study the political action committee we worked with advocated for passage of four initiatives and rejection of ten others, allowing us to

\footnotetext{
${ }^{1}$ Research on the question of whether initiative campaigns matter could be viewed as a subset of work on the question of whether political campaigns matter, in general. Of course, this question has a long history, with some suggesting that campaigns can matter but only under some circumstances, and others arguing that campaigns have no effect (Jacobson 1978; Erikson and Palfrey 2000; Green and Krasno 1988). Recent evidence from randomized experiments suggests that campaigns can influence voter preferences (Gerber 2004; Arceneaux 2005), but possibly for only a fleeting period (Gerber, Green and Shaw 2011).
} 
address the question of whether campaigns for and against initiatives are similarly effective (e.g.. Broder 2000; Garrett and Gerber 2001).

Studies using observational data and either regression frameworks or descriptive analyses have come to conflicting conclusions about the impact of initiative campaigns, offering three mutually exclusive claims about their impact. The first claim asserts that ballot initiative campaign spending has no effect on initiative outcomes. Gerber (1999), for example, argues that expenditures by organizations with minimal grassroots support relative to financial influence, called "economic groups", have no effect on whether an initiative passes, and may even have a negative effect. Groups that have stronger grassroots support appear to have trivial effect as well, they report, though not quite as negative (see also Bowler and Donovan 1998; Garrett and Gerber 2001).

The second claim is that initiative campaigns can be potent when advocating for initiative rejection, but not passage. This is supported by studies showing that when one side has more money than the other, rejection efforts are more effective (Lowenstein 1982; Owens and Wade 1986; Magleby 1984). Bowler and Donovan (1998) find similar results. After arguing that campaigns can affect initiative outcomes when opposing an initiative, they write "money spent by proponents in this arena is largely wasted" (as quoted in Strattman 2006, Bowler and Donovan 1998, p. 2).

The third claim says that initiative spending is effective regardless of whether advocating or opposing an initiative. For example, Strattman (2006) reaches this conclusion using data on television advertising spending across several California media markets for initiatives from 2000 to 2004. Others make similar arguments, suggesting that interest group spending can influence 
both passage and rejection of ballot initiatives (Ellis 2002; Schrag 1998; Smith 1998; see also Broder 2000 for a descriptive journalistic discussion of this perspective).

Our study yields results that are consistent with this last claim, finding that initiative spending, both for and against, has an effect on initiative outcomes. Further, we do not find an asymmetry in a campaign's impact based on whether it advocates for or against an initiative. Our findings are at odds with the claim that only campaigns advocating for passage of an initiative are effective and also at odds with the claim that initiative campaigns are ineffective, in general. Likewise, our results are at odds with the conclusion that groups without a widespread base of grassroots support, referred to as "economic groups," have no effects on ballot campaigns (Gerber 1999). The organization behind the advocacy program reported in this manuscript is an economic group because it does not have a broad base of individual financial supporters. In fact, it received $80 \%$ of its 2008 budget from 7 donors who each gave between $\$ 600,000$ and $\$ 5,300,000$ (Oregon Secretary of State).

Our research also, practically, shows that direct mail communications from campaigns to voters can influence voter preferences. The present study examines the effect of one to two communications sent by mail. The result may be surprising in light of the dozens of randomized field experiments have shown that get-out-the-vote mail tends to have trivial effects on turnout (see Green and Gerber, 2008 for a meta-analysis of these studies). Based on those findings, one might speculate that direct mail would have similarly small effects on vote choices.

Moreover, the mail used in this experiment was informational and did not clearly leverage any of the psychological principles shown to motivate voter participation (see Rogers, Gerber and Fox 2012). Green and Gerber (2008) report a meta-analysis suggesting that mailers that do not 
leverage specific psychological insights generate a miniscule 0.3 percentage point increase in turnout. A handful of studies have begun to address the question of how direct communications from campaigns to voters can affect voter preferences using regression discontinuity designs (Gerber, Kessler and Meredith 2011), precinct randomizations using a very small number of precincts (Gerber 2004; Keane and Nickerson 2012) and post-election surveys (Rogers and Nickerson 2012). The present research goes beyond this literature by offering a precise and unbiased estimate of the effect of ballot guides sent from a campaign directly to voters on voters' preferences across a diverse set of ballot initiatives.

\section{ELECTORAL CONTEXT}

This experiment was conducted during the 2008 General Election in the state of Oregon. There were twelve initiatives on the ballot. The exact text that appeared on the ballot is reprinted in Table 1. We collaborated with an advocacy organization that already planned to send ballot guides to voters. This organization took a position on each initiative, though, as we discuss below, two of the initiatives (54 and 55) were uncontested and, therefore, deemphasized in the treatment materials.

This election also included several high-profile races, including an election for US President and US Senate. In the Presidential race, Oregonians voted for Barack Obama over John McCain by more than a 16 percentage point margin. This meant that not much presidential campaign expenditure occurred in the state, though there was substantial discussion and volunteer activity regarding that race. The Senate race was expected to be one of the closest in the country and was also the target of substantial campaign expenditures. According to Federal Election Commission (FEC) records, the Senate race in Oregon between incumbent Republican Gordon Smith and 
Democrat Jeff Merkley was the most expensive per capita in the country in 2008. The FEC reports that $\$ 20$ million was spent by campaigns in Oregon for US Senate. An additional $\$ 10$ million was spent by campaigns in Oregon for US House, and \$11 million by registered PAC's in Oregon. FollowTheMoney.org documents that $\$ 54$ million was spent by state-level candidates and initiatives.

\section{RESEARCH DESIGN}

\section{Ballot Guides}

Defend Oregon targeted households in which one or more voters had a predicted probability of turnout greater than 0.3 . Turnout probability was estimated based on a model score provided by the commercial firm Catalist, LLC. $78.4 \%$ of all 1.5 million households were targeted, or, equivalently, an estimated $85 \%$ of households with at least one registered voter.

The advocacy organization mailed each targeted household at least one of five possible ballot guides (see Table 2 for distribution of how guides were targeted among treatment households). The guides can be divided into two categories, primary and secondary. Primary guides were sent to most targets, while secondary were sent to a smaller subset mostly as a second guide. The three types of primary guides were targeted to match the predicted ideology of the household as predicted based on data from the Catalist voter file (progressive, moderate or conservative). Among target households in treatment precincts, $13.8 \%$ were considered progressive and were sent a progressively framed ballot guide, which expressly mentioned the advocacy organization's publicly recognizable progressive partners. Households predicted to be politically moderate $(51.0 \%)$ received a moderately framed ballot guide, which was designed to appear especially even-handed. Households predicted to be conservative (31.4\%) received a conservatively 
framed guide, which framed the issues in terms of government waste and taxation. In total, $96.2 \%$ of the households that were sent any ballot guide from the advocacy organization received one of these three primary guides.

The other two types of ballot guides we refer to as secondary. The first of these was an education-oriented guide sent in addition to a primary guide, which was sent to households believed to contain children. The second of these guides targeted households headed by voters under 35 years old, many of which did not receive a primary guide. Of all targeted households in treatment precincts, $71.7 \%$ received no secondary guide, $24.1 \%$ received the education guide in addition to a primary guide, and $4.1 \%$ received the young voter guide.

The average number of ballot guides sent to a target household was 1.2. A vast majority (97.0\%) of the households that received more than one guide did so because they received the educationoriented guide in addition to a primary guide. In other words, households identified as having children make up nearly all of those who received more than one guide. A negligible amount of duplication occurred due to the vagaries of determining households based on imperfect address information and differences in the ways that households can be operationally defined based on this information.

The five ballot guides advocated for positions on different subsets of the 12 ballot measures. In Table 1 we show which measures were addressed in each of the ballot guides.

\section{Randomization}

The smallest unit at which election outcomes are officially reported is the political precinct. An experimental design that randomizes at the level of the precinct has many strengths, not the least 
of which is that the dependent variable is an official observed outcome that is free of sampling error and errors of self-report (see Keane and Nickerson, 2012; Gerber 2004; Arceneaux 2005).

We randomly assigned precincts to treatment or control before any treatments were administered using simple random assignment. Voters residing in precincts assigned to treatment were sent ballot guides based on the above criteria. Given the advocacy organization's needs, the total number of voters in our untreated control condition was limited to about $5 \%$ of the Oregon electorate. Given this constraint, we restricted the experimental universe to only the moderatelyand small-sized precincts. This approach maximized the total number of precincts in our study for a fixed number of voters in the control, thus improving statistical power. ${ }^{2}$

Seven hundred Oregon precincts were selected for inclusion in the study, 500 of which were assigned to treatment and 200 of which were assigned to control. Post-election, four of these 700 precincts (one control precinct and three treatment precincts, $0.6 \%$ of the initial 700 ) could not be matched to reported election returns. The total number of voters in the study was 320,921 , of which 91,540 were in the control group. According to the Oregon Secretary of State our experimental universe included approximately $18 \%$ of the Oregon electorate.

\section{Dependent Variables}

Our analysis examines four dependent variables. All are reported on public records of precinctlevel results made available by the Oregon Secretary of State. First, we estimate the net change

\footnotetext{
${ }^{2}$ We also pruned the universe before random assignment to eliminate precincts for which the reported number of registered voters varied by more than $20 \%$ between two different sources of registered voters per precinct.
} 
in vote margin for each ballot initiative due to treatment. This is our central outcome of interest because the ballot guides focused on supporting or opposing the initiatives. Second, we estimate the net change in voter turnout due to the treatment. Turnout could be affected if the treatment motivated citizens to cast a ballot, or, alternatively, discouraged citizens from voting. Third, we estimate the net change in the number of voters who "roll-off" or abstain from voting on the ballot measures, even though they cast a ballot to vote on other items. Voters may roll-off if they are uninformed about the initiatives. Because the treatment provided information and recommendations, voters who received the guides may have felt more informed and therefore willing to vote on the measures. Fourth, and finally, we consider whether treatment altered support for up-ballot candidates.

\section{Estimation}

Our analysis uses regression to estimate the average change in precinct-level vote margin due to treatment. Precinct-level vote margin is defined as the number of citizens voting for a ballot measure minus the number of citizens voting against that ballot measure, divided by the total number of ballots cast in the precinct. A vote margin between 0 and 1 indicates a majority voted for the measure and margin between 0 and -1 indicates a majority voted against.

Vote margin is regressed on the treatment indicator and, in the covariate adjusted version of this estimator, a measure of Democratic voting rates in the precinct based on past vote history. The model without covariates, model 1 , can be written

$$
y_{j}=\beta+t_{j} \beta_{t}+\varepsilon_{j}
$$

where $y_{j}$ is vote margin, $t_{j}$ is the treatment indicator, and $\varepsilon_{j}$ is an error term. The subscript $j$ indexes over precincts. The model with covariates, model 2, can be written 


$$
y_{j}=\beta+t_{j} \beta_{t}+\partial_{j} \beta_{\partial}+\omega_{j} \beta_{\omega}+\varepsilon_{j}
$$

where $\partial_{j}$ is a predictor of Democratic voting rates in the district (also in percentage terms) ${ }^{3}$, and $\omega_{j}$ indicates a missing value of $\partial_{j}$.

We estimate the models using ordinary least squares regression. Since $\varepsilon_{j}$ may be homoscedastic due to differing precinct sizes we use "robust" standard errors, though this does not affect the findings.

Collapsing the data at the precinct level is the customary approach to analyzing data of this sort. Some might object that the procedure is not consistent for estimating the average effects of the treatment at the level of the individual voter (see Middleton 2008; Middleton and Aronow 2011). These results are robust when using an unbiased, nonparametric, equally efficient estimator that is consistent for average individual-level effects. ${ }^{4}$

\section{RESULTS}

${ }^{3}$ The Democratic Performance Index (DPI) is a synthetic variable created by the National Center for an Effective Congress, designed to be broadly predictive of Democratic voting across political races. The index is designed to help political organizations make operational decisions about voter outreach campaigns. We use it as a covariate to improve the efficiency of our estimator, but give no causal interpretation to its coefficient. Since we use the DPI created before the 2008 election for use by political organizations during the 2008 campaign, we need not worry that this covariate is partially determined by the treatment and, hence, correlated with the treatment indicator.

${ }^{4}$ Interested readers should follow up with the authors. 
This section presents the estimates for the effect of the treatment on ballot measure support, turnout, roll-off and candidate support.

\section{Ballot Measure Vote Margin}

Table 3 shows that the treatment had sizable effects on vote margin for ten of the twelve ballot initiatives (56-64) in the intended directions. Among the ten, effects on vote margin ranged from 2.5 percentage points to 6 percentage points. It is notable that the treatment affected ten different electoral outcomes, not just one.

There were two initiatives unaffected by the treatment (54 and 55). Two unusual features of these initiatives may explain the lack of impact on their election outcomes. First, as described above, the advocacy organization sent treatment households up to two out of five ballot guides. Only one of the five ballot guides made reference to Initiatives 54 or 55 while each of the other ten were referred to in multiple guides; only $20 \%$ of targeted households received a ballot guide that referred to either of these two initiatives. Second, these two initiatives were unique in that they were essentially uncontested in terms of campaign activity and had lopsided vote margins, passing statewide with a $41.0 \%$ and $48.9 \%$ vote margin, respectively (i.e., $70.5 \%$ and $74.4 \%$ of votes cast for each initiative were cast in favor of the initiatives). This suggests that the vote margin may have reached a ceiling.

As discussed above, some research suggests that advocacy campaigns are ineffective, in particular when: a. the advocating organization is an economic group with few grassroots members (Gerber 1999); or b. the advocating group is advocating for passage of an initiative (Broder 2000; Garrett and Gerber 2001). We note that the advocacy organization that sent these 
mailings qualifies as an economic group, and that Table 3 shows that they significantly and substantively increased support for passing Initiatives 56 and 57.

Finally, Table 3 shows that the treatment effect for Initiatives 61 and 64 was greater than the statewide vote margin for the initiatives. Put differently, Initiative 61 (about mandatory drug sentencing) was defeated by 2.2 percentage points statewide, and the treatment decreased support for it in our experiment universe by about 5 or 6 percentage points in the average precinct; Initiative 64 (about how political funds can be spent) was defeated by 1.0 percentage point statewide, and the treatment decreased support for it in our experimental universe by about 5 or 6 percentage points in the average precinct. If we assume that the treatment effect in our experimental universe generalizes to the larger Oregon precincts that were excluded from this study (but in which the advocacy organization conducted the exact same program), then we can say that if not for the advocacy campaign the electoral outcomes of these two initiatives would have been otherwise. ${ }^{5}$ Even if the average effect outside the experimental universe were a fraction of these estimates, the election outcomes would still be attributable to the campaign.

\section{Ballot Roll-off Rates}

\footnotetext{
${ }^{5}$ We cannot prove, statistically, that the treatment effect in our experimental universe would generalize to the large precincts outside of our experiment universe. That said, we find no relationship in our experimental universe between precinct size and treatment effect. This suggests that the advocacy organization's treatment may have resulted in similar average treatment effects in Oregon's large precincts as we found in our experiment universe of smalland moderately-sized precincts.
} 
Table 4 reports how treatment affected the rates of ballot "roll-off" for each of the initiatives. A voter exhibits roll-off when s/he votes in high profile races, such as President or US Senate, but fails to vote on lower salience items such as ballot initiatives. We calculate roll-off for a given precinct by subtracting the total number of votes cast for a given initiative from the total number of votes cast for the race with the greatest number of total votes cast (which was always the Presidential election). Results suggest that roll-off was not affected for eleven out of twelve initiatives, suggesting that the mailings did not have a substantive effect on increasing ballot completion.

For Initiative 65 there is some evidence that roll-off was reduced. We do not interpret this as particularly meaningful given the relatively small effect size, the lack of effects on the other initiatives, and a nonsignificant result in the nonparametric analysis (available upon request). Moreover, given the sheer number of statistical tests being conducted as part of this project, we might expect to see one or two coefficients achieving statistical significance just by chance.

\section{Turnout}

Table 5 shows the treatment had no meaningful effect on turnout. A body of work on the impact of ballot initiatives on the electorate suggests that the presence of initiatives increases turnout, in general (Tolbert, Grummel, and Smith 2001), or in Midterm elections but not Presidential elections (Smith, 2001). The absence of a turnout effect in the present experiment only tangentially speaks to that work. This is because both lines of that research suggest that the increases in turnout come from the introduction of a ballot initiative into an election (and the ensuing initiative campaign), while the current study focuses on changing voters' preferences on ballot initiatives that had already been introduced into the election in that state. Whatever turnout 
affect arises from the introduction of a given initiative in a state should already have been incorporated into voters' likelihoods of voting before our treatment was administered.

The fact that our treatment did not affect voter turnout suggests that people do not fail to vote because they are uninformed since our treatments were informative about the ballot initiatives. Since the results are reported at the cluster level (the precincts) one might suggest that the treatment results are averages that mask an increase in turnout among some voters (e.g., Democrats), and a decrease in turnout in equal measure among others (e.g., Republicans). We examined the individual-level voter file data to look for evidence of heterogeneous treatment effects. We found no significant interactions between treatment assignment and the demographic attributes on file: gender, party registration or age.

\section{Effects on Candidate Races}

Table 6 presents the results for candidate races. Results are mixed, with estimates suggesting that treatment may have increased votes for the Democratic Senatorial, House, and State Senate candidates. However, the covariate adjusted estimates are greatly diminished, and the results are not replicated using a nonparametric estimation approach, available upon request. Because of this lack of robustness, the results do not support an interpretation that ballot guides affected upballot races.

\section{GENERAL DISCUSSION}

We present the first well-powered cluster-randomized field experiment showing that an independent organization advocating for and against a suite of ballot initiatives can have a consequential and significant effect on initiative outcomes. This contrasts with findings suggesting that campaigns do not have an effect on initiative outcomes (Gerber 1999; Bowler 
and Donovan 1998) and work suggesting that only campaigns against initiatives are effective (Broder 2000; Garrett and Gerber 2001). We find that the campaign's impact on win margin for these initiatives did not influence turnout or roll-off. This pattern of results suggests that the campaign affected vote margin by altering ballot preferences among those who would have cast their vote on the initiatives anyway, but in the opposite direction.

To calculate cost per additional vote added to vote margin we use the following equation:

$$
(\mathrm{A} * \mathrm{~B}) /(\mathrm{C} * \mathrm{D})
$$

The variable A is the treatment cost per targeted household. Targeted households received an average of 1.2 mailings, so if we assume each mailing cost $\$ 0.75$, then it cost $\$ .90$ per targeted household. The variable B is the proportion of all households containing a registered voter in the experiment universe that were targeted. As reported above, $85 \%$ of households in the experiment universe with at least one registered voter were targeted. The variable $\mathrm{C}$ is the average impact on vote margin for each of the twelve advocated for initiatives. Using the covariate adjusted estimates from Table 3 the average impact on each initiative's vote margin is 3.5 percentage points. The variable $\mathrm{D}$ is the number of initiatives for which the treatment advocated. There were twelve initiatives advocated for by this treatment. Calculated this way, the treatment yielded an additional vote in the vote margin in the favored direction for each initiative at $\$ 1.84$.

This is a low cost. For example, get-out-the-vote efforts involving two pieces of standard mail that do not reflect recent innovations from psychological insights costs around $\$ 400$ to $\$ 500$ per increased voter (see Green and Gerber 2008). Cost effectiveness is not as well studied for persuasive mail communications. Another persuasion campaign conducted in 2008 in Oregon 
(Rogers and Nickerson 2012) targeted self-identified pro-choice voters and tried to correct the misinformation that the incumbent Senator was pro-life and not pro-choice (he was actually prochoice). That campaign found that it cost $\$ 40$ per additional vote added to the voter margin in the favored direction.

Why might the cost per net vote for each initiative have been low in this election? We speculate that voters may be especially receptive to the style of the treatment studied: factual, seemingly objective, and, for four out of five versions, ostensibly non-political summaries of multiple ballot initiatives. One might still find the effect magnitudes surprising in light of the hotly contested political context in Oregon in 2008. However, inundated with political communications for a variety of contests, recipients may have responded positively to the systematic and clear vote recommendations provided in a compact format. Indeed, theories of bounded attention (Gabaix, Laibson, Moloche, and Weinberg 2003) suggest that in noisy election environments voters may place a premium on these kinds of efficient communications - so long as they are perceived to be credible. Future research should assess whether this kind of treatment is, in fact, especially effective in hotly contested elections as opposed to less cluttered election environments.

Another reason for the ballot guide effectiveness may be that they were delivered directly to voters' homes, since all ballots are cast by mail in Oregon. This all vote-by-mail election may have created the conditions whereby voters may have completed their ballots at home with the ballot guide present to inform their decisions. Future research should explore whether vote-bymail moderates the effectiveness of persuasive ballot guides. This might be testable by studying ballot guide effectiveness in precincts with total populations that are just above and below the number where vote-by-mail becomes mandatory (see Meredith and Malhotra 2008). 
We report inconsistent results on the impact of the ballot guides on up-ballot candidate support. The results are not robust enough to take seriously, but they are provocative. Support for upballot candidates could be altered if treatments that affect preferences on ballot measures also prime issues or preferences that change the way the candidate choice is construed (Iyengar and Kinder, 1987; Krosnick and Kinder, 1990). If replicated more robustly a finding like this would suggest that influencing voter preferences for down-ballot initiatives may affect preferences for up-ballot contests like US Senate and US Congress. We hope future research explores this possibility.

Finally, the organization that conducted this mail program was financially supported by a small group of donors. Therefore, our findings are inconsistent with work suggesting that organizations without broad financial support of grassroots donors, so-called economic organizations, have trivial effects on initiative outcomes (Gerber 1999). That economic organizations can influence initiative outcomes has normative implications, particularly because ballot initiatives are often described as giving the people, not interest groups, direct democratic power to decide important policy issues. As such, our findings may provide fodder for those who wish to regulate campaign funding. 


\section{References}

Arceneaux, Kevin. 2005. "Using Cluster Randomized Field Experiments to Study Voting Behavior." In The Science of Voter Mobilization: The Annals of the American Academy of Political and Social Science 601: 169-179. Eds Donald Green and Aland Gerber.

Arceneaux, Kevin and Robin Kolodny. "Educating the Least Informed: Group Endorsements in a Grassroots Campaign.” American Journal of Political Science 53(4): 755-770.

Bowler, Shaun and Todd Donovan. 1998. Demanding Choices: Opinion and Voting in Direct Democracy. Ann Arbor: University of Michigan Press.

Broder, David S. 2000. Democracy Derailed: Initiative Campaigns and the Power of Money. New York: Harcourt.

Ellis, Richard. 2002. Democratic Delusions: The Initiative Process in America. Lawrence: University of Kansas.

Erikson, Robert S., and Thomas R. Palfrey. 2000. "Equilibria in Campaign Spending Games: Theory and Evidence." American Political Science Review 94 (3): 595-609.

Gabaix, Xavier, David Laibson, Guillermo Moloche, and Stephen Weinberg. 2006. "Costly Information Acquisition: Experimental Analysis of a Boundedly Rational Model.” American Economic Review 96 (4): 1043-1068.

Garrett, Elizabeth and Elisabeth R. Gerber. 2001. "Money in the Initiative and Referendum Process: Evidence of its Effects and Prospects for Reform." In The Battle over Citizen Lawmaking: 73-95. Durham, N.C.: Carolina Academic Press. Ed M. Dane Waters.

Gerber, Alan and Donald Green. 2000. "The Effects of Canvassing, Telephone Calls, and Direct Mail on Voter Turnout: A Field Experiment." American Political Science Review 94 (3): 653-663. 
Gerber, Alan. 2004. "Does Campaign Spending Work? Field Experiments Provide Evidence and Suggest New Theory.” American Behavioral Scientist 47 (5): 541-74.

Gerber, Elisabeth. 1999. The Populist Paradox: Interest Group Influence and the Promise of Direct Legislation. Princeton, NJ: Princeton University Press.

Gerber, Alan S., James G. Gimpel, Donald P. Green, and Daron R. Shaw (2011). "How Large and Long-lasting Are the Persuasive Effects of Televised Campaign Ads? Results from a Randomized Field Experiment.” American Political Science Review, 105 (1): 135-150.

Gerber, Alan S., Daniel P. Kessler, and Marc Meredith (2011). “The Persuasive Effects of Direct Mail: A Regression Discontinuity Based Approach.” The Journal of Politics, 73 (1): 140155.

Green, Donald P., and Alan S. Gerber. 2008. Get Out the Vote: How to Increase Voter Turnout. Washington, D.C.: Brookings Institution Press.

Green, Donald P., and Jonathan S. Krasno. 1988. "Salvation for the Spendthrift Incumbent." American Journal of Political Science 32 (4): 884-907.

Holbrook, Thomas M. 1996. Do Campaigns Matter? Thousand Oaks, CA: Sage Publications, Inc.

Initiative and Referendum Institute. 2000. http://www.iandrinstitute.org Iyengar, Shanto, and Donald R. Kinder. 1987. News That Matters: Television and American Opinion. Chicago: University of Chicago.

Jacobson, Norman. 1978. Pride and Solace: The Functions and the Limits of Political Theory. Berkeley, CA: University of California Press.

Keane, Lauren and David Nickerson. 2012. “A Field Experiment on Nonpartisan Mobilization and Persuasion Down-Ballot" Unpublished manuscript. 
Lenz, Gabriel S. 2009. "Learning and Opinion Change, Not Priming: Reconsidering the Priming Hypothesis." American Journal of Political Science 53 (4): 821-837.

Lowenstein, Daniel H. 1982. "Campaign Spending and Ballot Propositions: Recent Experience, Public Choice Theory and the First Amendment." UCLA Law Review 29 (3): 505-641.

Krosnick, Jon A. and Donald R. Kinder. 1990. "Altering the Foundations of Support for the President Through Priming.” American Political Science Review 84 (2): 497-512.

Magleby, David. 1984. Direct Legislation: Voting on ballot Propositions in the United States. Baltimore, MD: Johns Hopkins University Press.

Meredith, Mark and Neil Malhotra. 2008. "Can October Surprise: A Natural Experiment Assessing Late Campaign Effects.” Stanford Graduate School of Business Research Paper Number 2002.

Michelson, Melissa R. 2006-2007. "Mobilizing Latino Voters for a Ballot Proposition." Latino(a) Research Review 6, 1-2 (Summer): 33-49.

Middleton, Joel A. 2008. "Bias of the Regression Estimator for Experiments Using Clustered Random Assignment." Statistics \& Probability Letters 78: 2654-2659.

Middleton, Joel A. and Peter M. Aronow. 2011. Unbiased Estimation of the Average Treatment Effect in Cluster-Randomized Experiments. Paper Presented at the Annual Meeting of the Midwest Political Science Association. Chicago.

Nicholson, Stephen P. 2003. "The Political Environment and Ballot Proposition Awareness." American Journal of Political Science 47: 403-410.

Nickerson, David W. and Todd Rogers. 2010. "Do You Have a Voting Plan? Implementation Intentions, Voter Turnout, and Organic Plan Making. ”Psychological Science 21 (2): 194-199. 
Online Voters' Guide for November 4, 2008 General Election.

http://www.sos.state.or.us/elections/pages/history/archive/nov42008/guide/cover.html

Owens, John R. and Larry L. Wade. 1986. “Campaign Spending on California Ballot

Propositions, Trends and Effects, 1924-1984." Western Political Quarterly 39 (4): 67589.

Rogers, Todd, Alan S. Gerber, Craig R. Fox. 2012. "Rethinking Why People Vote: Voting as Dynamic Social Expression.” In Behavioral Foundations of Policy. New York: Russell Sage Foundation. Ed E. Shafir.

Rogers, Todd and David Nickerson. 2012. "Correcting Information about Candidate Positions." Unpublished manuscript.

Schrag, Peter. 1998. Paradise Lost: California's Experience, America's Future. New York: New Press.

Smith, Daniel A. 1998. Tax Crusaders and the Politics of Direct Democracy. New York: Routledge.

Smith, Mark. 2001. "The Contingent Effects of Ballot Initiatives and Candidate Races on Turnout." American Journal of Political Science 45 (3): 700-706.

Smith, Daniel A. 2001. "Homeward Bound?: Micro-Level Legislative Responsiveness to Ballot Initiatives.” State Politics and Policy Quarterly 1 (Spring): 50-61.

Stratmann, Thomas. 2005. "Some Talk: Money in Politics. A (partial) review of the literature." Public Choice, 124:1-2, 135-156.

Stratmann, Thomas. 2006. "Is Spending More Potent For or Against a Proposition? Evidence from Ballot Measures.” American Journal of Political Science 50 (3): 788-801. 
Tolbert, Caroline and Daniel Smith. 2005. "The Educative Effects of Ballot Initiatives on Voter Turnout." American Politics Research 33: 283-309.

Tolbert, Caroline, John Grummel, and Daniel Smith. 2001. "The Effect of Ballot Initiatives on Voter Turnout in the American States." American Politics Research 29: 625-648. 
Table 1: Ballot Measures, Defend Oregon's Positions and Electoral Outcomes

\begin{tabular}{|c|c|c|c|c|c|c|c|c|c|c|}
\hline Measure & Description as Printed on Ballot & 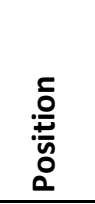 & 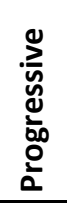 & $\begin{array}{l}\stackrel{ \pm}{\pi} \\
\frac{\pi}{2} \\
\frac{0}{0} \\
\sum \\
\end{array}$ & 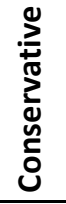 & 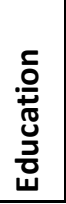 & 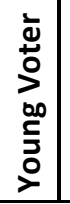 & Yes votes & No votes & Result \\
\hline 54 & $\begin{array}{l}\text { Amends Constitution: Standardizes voting eligibility for school } \\
\text { board elections with other state and local elections. }\end{array}$ & Pro & $\mathrm{x}$ & & & & & $1,194,173$ & 450,979 & Pass \\
\hline 55 & $\begin{array}{l}\text { Amends Constitution: Changes operative date of redistricting } \\
\text { plans; allows affected legislators to finish term in original district. }\end{array}$ & Pro & $x$ & & & & & $1,251,478$ & 364,993 & Pass \\
\hline 56 & $\begin{array}{l}\text { Amends Constitution: Provides that May and November property } \\
\text { tax elections are decided by majority of voters voting. }\end{array}$ & Pro & $\mathrm{x}$ & $\mathrm{x}$ & $\mathrm{x}$ & $\mathrm{x}$ & $\mathrm{x}$ & 959,118 & 735,500 & Pass \\
\hline 57 & $\begin{array}{l}\text { Increases sentences for drug trafficking, theft against elderly and } \\
\text { specified repeat property and identity theft crimes; requires } \\
\text { addiction treatment for certain offenders. }\end{array}$ & Pro & $\mathrm{x}$ & $\mathrm{x}$ & $\mathrm{x}$ & & $\mathrm{x}$ & $1,058,955$ & 665,942 & Pass \\
\hline 58 & $\begin{array}{l}\text { Prohibits teaching public school student in language other than } \\
\text { English for more than two years }\end{array}$ & Anti & $\mathrm{x}$ & $\mathrm{x}$ & $\mathrm{x}$ & $\mathrm{x}$ & $\mathrm{x}$ & 756,903 & 977,696 & Fail \\
\hline 60 & $\begin{array}{l}\text { Teacher "classroom performance," not seniority, determines pay } \\
\text { raises; "most qualified" teachers retained, regardless of seniority }\end{array}$ & Anti & $\mathrm{x}$ & $\mathrm{x}$ & & $\mathrm{x}$ & $x$ & 673,296 & $1,070,682$ & Fail \\
\hline 61 & $\begin{array}{l}\text { Creates mandatory minimum prison sentences for certain theft, } \\
\text { identity theft, forgery, drug, and burglary crimes }\end{array}$ & Anti & $\mathrm{x}$ & $\mathrm{x}$ & $x$ & & $\mathrm{x}$ & 848,901 & 887,165 & Fail \\
\hline 62 & $\begin{array}{l}\text { Amends Constitution: Allocates } 15 \% \text { of lottery proceeds to public } \\
\text { safety fund for crime prevention, investigation, prosecution }\end{array}$ & Anti & $x$ & $x$ & $x$ & $x$ & $x$ & 674,428 & $1,035,756$ & Fail \\
\hline 63 & $\begin{array}{l}\text { Exempts specified property owners from building permit } \\
\text { requirements for improvements valued at/under } 35,000 \text { dollars }\end{array}$ & Anti & $x$ & $x$ & $x$ & & $\mathrm{X}$ & 784,376 & 928,721 & Fail \\
\hline 64 & $\begin{array}{l}\text { Penalizes person, entity for using funds collected with "public } \\
\text { resource" (defined) for "political purpose" (defined) }\end{array}$ & Anti & $x$ & $x$ & & $x$ & $x$ & 835,563 & 854,327 & Fail \\
\hline 65 & $\begin{array}{l}\text { Changes general election nomination processes for major/minor } \\
\text { party, independent candidates for most partisan offices }\end{array}$ & Anti & & $x$ & $x$ & & & 553,640 & $1,070,580$ & Fail \\
\hline
\end{tabular}


Table 2: Relative Frequencies of Combinations of Primary and Secondary Guides

\begin{tabular}{|c|c|c|c|c|c|c|}
\hline & \multicolumn{4}{|c|}{ Secondary Guides } & \multirow[b]{2}{*}{ Total } \\
\hline & & No secondary guide & Education & Young voter & Both & \\
\hline \multirow{5}{*}{ 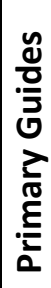 } & Progressive & $10.4 \%$ & $3.3 \%$ & $a$ & $a$ & $13.8 \%$ \\
\hline & Moderate & $35.3 \%$ & $15.4 \%$ & $a$ & $a$ & $51.0 \%$ \\
\hline & Conservative & $25.9 \%$ & $5.2 \%$ & $a$ & $a$ & $31.4 \%$ \\
\hline & No primary guide & $a$ & $a$ & $3.6 \%$ & $a$ & $3.8 \%$ \\
\hline & More than one & $a$ & $a$ & $a$ & $a$ & $a$ \\
\hline & Total & $71.7 \%$ & $24.1 \%$ & $4.1 \%$ & $a$ & $100.0 \%$ \\
\hline
\end{tabular}

${ }^{a}$ Fewer than $0.3 \%$ of targeted households were sent this combination of guides.

Note: Percentages represent relative frequencies of guide combinations over all targeted households in experimental precincts.

Percentages lower than $0.3 \%$ are omitted from the table for clarity but are included in the marginal percentages. In total only $0.9 \%$ of households fell in to omitted cells. 
Table 3: Estimated Effects on Ballot Measure Vote Margin

\begin{tabular}{|c|c|c|c|c|}
\hline Measure & Position & \multicolumn{2}{|c|}{ collapsed data reg. } & $\begin{array}{c}\text { Actual } \\
\text { Statewide } \\
\text { Vote Margin }\end{array}$ \\
\hline 54 & Pro & $\begin{array}{l}0.8 \\
(1.3)\end{array}$ & $\begin{array}{l}0.6 \\
(1.2)\end{array}$ & $411.0 \%$ \\
\hline 55 & Pro & $\begin{array}{l}-0.4 \\
(1.2)\end{array}$ & $\begin{array}{l}-0.4 \\
(1.2)\end{array}$ & $48.9 \%$ \\
\hline 56 & Pro & $\begin{array}{l}4.2^{* * *} \\
(1.5)\end{array}$ & $\begin{array}{l}3.3^{* * *} \\
(1.2)\end{array}$ & $12.3 \%$ \\
\hline 57 & Pro & $\begin{array}{l}4.6^{* * *} \\
(1.2)\end{array}$ & $\begin{array}{l}4.2 * * * \\
(1.2)\end{array}$ & $21.7 \%$ \\
\hline 58 & Anti & $\begin{array}{l}-5.9 * * * \\
(1.8)\end{array}$ & $\begin{array}{l}-4.9 * * * \\
(1.3)\end{array}$ & $-12.2 \%$ \\
\hline 59 & Anti & $\begin{array}{l}-4.9 * * * \\
(1.5)\end{array}$ & $\begin{array}{l}-4.2^{* * *} \\
(1.3)\end{array}$ & $-25.9 \%$ \\
\hline 60 & Anti & $\begin{array}{l}-4.1^{* * *} \\
(1.5)\end{array}$ & $\begin{array}{l}-3.3^{* * *} \\
(1.2)\end{array}$ & $-21.9 \%$ \\
\hline $61+$ & Anti & $\begin{array}{l}-6.0 * * * \\
(1.7)\end{array}$ & $\begin{array}{l}-5.0 * * * \\
(1.4)\end{array}$ & $-2.1 \% \dagger$ \\
\hline 62 & Anti & $\begin{array}{l}-6.0 * * * \\
(1.5)\end{array}$ & $\begin{array}{l}-5.1^{* * *} \\
(1.4)\end{array}$ & $-19.9 \%$ \\
\hline 63 & Anti & $\begin{array}{l}-3.6^{*} \\
(2.3)\end{array}$ & $\begin{array}{l}-2.5^{*} \\
(1.8)\end{array}$ & $-8.0 \%$ \\
\hline $64+$ & Anti & $\begin{array}{l}-5.9 * * * \\
(1.6)\end{array}$ & $\begin{array}{l}-5.1 * * * \\
(1.3)\end{array}$ & $-1.0 \%+$ \\
\hline 65 & Anti & $\begin{array}{l}-4.1^{* * *} \\
(1.0)\end{array}$ & $\begin{array}{l}-4.5^{* * *} \\
(1.0)\end{array}$ & $-28.5 \%$ \\
\hline
\end{tabular}

Note: Results presented in percentage points. Estimates represent the number of citizens voting for a ballot measure in a precinct minus the number of citizens voting against that ballot measure in the precinct, divided by the total number of ballots cast in the precinct; $\uparrow$ signifies estimated treatment effect greater than the statewide vote margin for the initiative. If the results generalize to all treatment recipients, not just those recipients in the study, then we would conclude that the initiative failed as a result of the advocacy organization's effort. 
Table 4: Estimated Effects on Ballot Roll-off Rates

\begin{tabular}{|c|c|c|c|}
\hline \multirow[b]{2}{*}{ Measure } & \multirow[b]{2}{*}{ Position } & \multicolumn{2}{|c|}{ collapsed data reg. } \\
\hline & & (1) & (2) \\
\hline \multirow[t]{2}{*}{54} & Pro & 0.4 & 0.3 \\
\hline & & $(0.3)$ & $(0.3)$ \\
\hline \multirow[t]{2}{*}{55} & Pro & 0.3 & 0.1 \\
\hline & & (0.4) & $(0.4)$ \\
\hline \multirow[t]{2}{*}{56} & Pro & -0.2 & -0.4 \\
\hline & & $(0.4)$ & $(0.4)$ \\
\hline \multirow[t]{2}{*}{57} & Pro & -0.1 & -0.2 \\
\hline & & (0.3) & $(0.3)$ \\
\hline \multirow[t]{2}{*}{58} & Anti & 0.0 & 0.0 \\
\hline & & $(0.2)$ & $(0.2)$ \\
\hline \multirow[t]{2}{*}{59} & Anti & 0.1 & -0.1 \\
\hline & & $(0.3)$ & $(0.3)$ \\
\hline \multirow[t]{2}{*}{60} & Anti & 0.4 & 0.4 \\
\hline & & $(0.4)$ & $(0.4)$ \\
\hline \multirow[t]{2}{*}{61} & Anti & 0.2 & 0.1 \\
\hline & & $(0.4)$ & $(0.4)$ \\
\hline \multirow[t]{2}{*}{62} & Anti & -0.1 & -0.3 \\
\hline & & $(0.3)$ & $(0.3)$ \\
\hline \multirow[t]{2}{*}{63} & Anti & 0.3 & 0.1 \\
\hline & & $(0.3)$ & $(0.3)$ \\
\hline \multirow[t]{2}{*}{64} & Anti & 0.2 & 0.1 \\
\hline & & $(0.3)$ & $(0.3)$ \\
\hline \multirow[t]{2}{*}{65} & Anti & $-0.7 * *$ & $-0.9 * * *$ \\
\hline & & $(0.4)$ & $(0.3)$ \\
\hline
\end{tabular}

$$
* \mathrm{p}<0.10 * * \mathrm{p}<0.05 * * * \mathrm{p}<0.01 \quad \text { (one-tailed) }
$$

Note: Results presented in percentage points. Estimates represent the total number of votes cast for the race with the greatest number of total votes cast (which was always the Presidential election) minus the total number of votes cast for a given initiative in a precinct minus. 
Table 5: Estimated Effects on Turnout

\begin{tabular}{|c|c|c|}
\hline & \multicolumn{2}{|c|}{ collapsed data reg. } \\
& (1) & (2) \\
\hline \hline \multirow{2}{*}{ Turnout } & 0.3 & 0.3 \\
& $(0.4)$ & $(0.4)$ \\
\hline
\end{tabular}

$* \mathrm{p}<0.10 * * \mathrm{p}<0.05 * * * \mathrm{p}<0.01 \quad$ (one-tailed)

Note: Results presented in percentage points. Estimates represent the total number of ballots cast in the treatment precincts minus the total number of ballots cast in control precincts. 
Table 6: Estimated Effects on Candidate Races

\begin{tabular}{|c|c|cc|}
\hline \multirow{2}{*}{$\begin{array}{c}\text { number of } \\
\text { precincts }\end{array}$} & Race & \multicolumn{2}{|c|}{ collapsed data reg. } \\
\hline \hline 696 & President & 1.8 & 0.2 \\
& & $(2.6)$ & $(1.5)$ \\
696 & Senate & $4.2^{* *}$ & $2.8^{* *}$ \\
& & $(2.5)$ & $(1.4)$ \\
512 & House & $9.4^{* *}$ & 3.1 \\
& & $(4.8)$ & $(3.5)$ \\
696 & Secretary & 2.2 & 0.5 \\
& of State & $(2.3)$ & $(1.4)$ \\
696 & State & 2.2 & 1.0 \\
& Treasurer & $(2.1)$ & $(1.3)$ \\
& & & \\
216 & State & $6.4^{*}$ & 1.0 \\
& Senate & $(4.5)$ & $(3.1)$ \\
& State & 1.0 & -0.1 \\
& House & $(3.3)$ & $(2.4)$ \\
& & & \\
\hline
\end{tabular}

$$
* \mathrm{p}<0.10 * * \mathrm{p}<0.05 * * * \mathrm{p}<0.01 \quad \text { (one-tailed) }
$$

Note: Results presented in percentage points. Estimates represent the total number of votes cast in the treatment precincts for the Democratic candidate minus the total number of votes cast in control precincts for the Republican candidate. 